UDK 342.9

DOI: 10.54649/2077-9860-2020-4-45-52

\author{
A.M. Satbayeva ${ }^{1}$ \\ ${ }^{1}$ candidate of law sciences, \\ High School of Business and Law, \\ Kazakh National Agrarian Research University, \\ Republic of Kazakhstan, Almaty \\ E-mail: sathaeva@mail.ru \\ Zh.M. Amanzholov ${ }^{2}$ \\ ${ }^{2}$ candidate of law sciences, \\ High School of Business and Law, \\ Kazakh National Agrarian Research University, \\ Republic of Kazakhstan, Almaty
}

\title{
ENVIRONMENTAL PROTECTION IN AGRICULTURE: PROSPECTS FOR APPROXIMATION OF THE LEGISLATION OF THE REPUBLIC OF KAZAKHSTAN AND THE EURASIAN UNION
}

\begin{abstract}
Annotation
In this article the main directions of legal regulation of environmental protection and rational use of natural resources in agrarian relations are investigated. The leading policy documents of the Eurasian Union and the Republic of Kazakhstan, securing the main directions for the development of agriculture, are analyzed, promising areas of convergence of the laws of the Republic of Kazakhstan and the Eurasian Union in the field of rational use of natural resources and environmental protection in the implementation of agricultural activities are identified. The main trends in the improvement of normative legal acts operating in the considered sphere of public relations are revealed on the basis of a comparative legal analysis of the legislation of the Republic of Kazakhstan, the Eurasian Union and some CIS countries (Russia, Ukraine). Proposals have been formulated for the greening of the agrarian legislation of the Republic of Kazakhstan, taking into account the principle of sustainable development. The necessity of developing and adopting a legislative act (law) regulating the complex of relations in the field of the agro-industrial complex, including environmental protection in agriculture, is substantiated.

Keywords: environmental protection, natural resources, implementation, greening, sustainable development, agro-industrial complex, environmental policy, ecological approach.
\end{abstract}

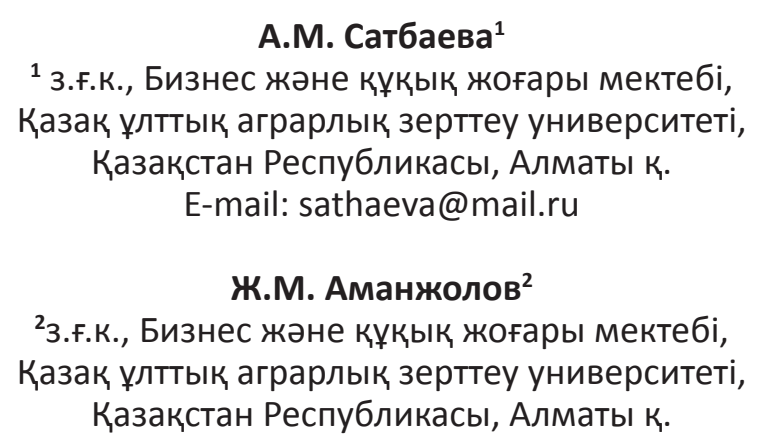




\title{
Аңдатпа
}

Мақалада қоршағанортаны қорғаудыжәнеаграрлыққатынастардатабиғиресурстардыұтымды пайдалануды құқықтық реттеудің негізгі бағыттары қарастырылған, ауылшаруашылық қызметін жүзеге асыруда табиғи ресурстар мен қоршаған ортаны қорғау анықталған. Еуразиялық одақ пен Қазақстан Республикасының ауыл шаруашылығын дамытудың негізгі бағыттарын бекітетін жетекші бағдарламалық құжаттары, Қазақстан Республикасы мен Еуразиялық Одақтың ауыл шаруашылығын тиімді пайдалану саласындағы заңнамасының жақындасуының перспективалық бағыттары талданған. Қазақстан Республикасының, Еуразиялық Одақтың және ТМД-ның кейбір елдерінің (Ресей, Украина) қарастырылып отырған қоғамдық қатынастар саласындағы нормативтік құқықтық актілерді жетілдірудің негізгі тенденциялары анықталды. Ұзақ мерзімді даму қағидасын ескере отырып, Қазақстан Республикасының аграрлық заңнамасын экологизациялау, жасылдандыру бойынша ұсыныстар жасалды. Агроөнеркәсіптік кешен саласындағы қатынастар кешенін, оның ішінде ауыл шаруашылығында қоршаған ортаны қорғауды реттейтін заңнамалық актіні (заң) әзірлеу және қабылдау қажеттілігі негізделді.

Түйінді сөздер: қоршаған ортаны қорғау, табиғи ресурстар, іске асыру, көгалдандыру, тұрақты даму, агроөнеркәсіп кешені, экологиялық саясат, экологиялық тәсіл.

\author{
А.М. Сатбаева ${ }^{1}$ \\ ${ }^{1}$ к.ю.н., Высшая школа бизнеса и права, \\ Казахский национальный исследовательский аграрный университет, \\ Республика Казахстан, г. Алматы \\ E-mail: sathaeva@mail.ru \\ Ж.М. Аманжолов \\ 2 к.ю.н., Высшая школа бизнеса и права, \\ Казахский национальный исследовательский аграрный университет, \\ Республика Казахстан, г. Алматы
}

\section{ОХРАНА ОКРУЖАЮЩЕЙ СРЕДЫ В СЕЛЬСКОМ ХОЗЯЙСТВЕ: ПЕРСПЕКТИВЫ СБЛИЖЕНИЯ ЗАКОНОДАТЕЛЬСТВА РЕСПУБЛИКИ КАЗАХСТАН И ЕВРАЗИЙСКОГО СОЮЗА}

\begin{abstract}
Аннотация
В статье исследуются основные направления правового регулирования охраны окружающей среды и рационального использования природных ресурсов в аграрных отношениях. Анализируются ведущие программные документы Евразийского союза и Республики Казахстан, закрепляющие основные направления развития сельского хозяйства, перспективные направления сближения законодательства Республики Казахстан и Евразийского союза в области рационального использования сельскохозяйственных культур, определены природные ресурсы и охрана окружающей среды при осуществлении сельскохозяйственной деятельности. На основе сравнительно-правового анализа законодательства Республики Казахстан, Евразийского союза и некоторых стран СНГ (Россия, Украина) выявлены основные тенденции совершенствования нормативных правовых актов, действующих в рассматриваемой сфере общественных отношений. Сформулированы предложения по экологизации аграрного законодательства Республики Казахстан с учетом принципа устойчивого развития. Обоснована необходимость разработки и принятия законодательного акта (закона), регулирующего комплекс отношений в сфере агропромышленного комплекса, включая охрану окружающей среды в сельском хозяйстве.

Ключевые слова: охрана окружающей среды, природные ресурсы, реализация, озеленение, устойчивое развитие, агропромышленный комплекс, экологическая политика, экологический подход.

Ensuring environmental safety in agricultural production is of particular relevance in connection with the constant development of the agro-industrial complex and, as a consequence, an increase in the harmful impact on the environment.

The need to comply with the requirements in the field of environmental protection and rational use of natural resources is due to the

high level of negative impact on all natural resources - land, water, subsoil, atmospheric air, the natural environment as a whole as the basis of agriculture, as well as possible adverse consequences for humans. In order to achieve sustainable development of agriculture and consistent implementation of agricultural policy, it is necessary to resolve a number of issues, which include the issue of determining a regulatory legal
\end{abstract}


act that should consolidate the foundations of environmental policy for the agricultural sector of the economy. At present, there is no single normative legal act in the Republic of Kazakhstan that establishes the basis of the state's agrarian policy. The existing system of requirements for rationaluse of natural resourcesand environmental protection does not reflect an integrated socioeconomic and ecological approach. The modern agricultural policy of the state should take into account the principle of sustainable development and, in the process of implementation, be based on a unified approach to ensuring rational use of natural resources and environmental protection in agriculture.

Ensuring environmental protection in agriculture is a necessary element of international policy, since the most intense pollution of the environment, as well as other negative impact on it, occurs precisely in the process of human economic activity, the harm from which must be minimized. As a result of these reasons, the environmental issues in the development of agriculture policy are among the international and national priorities of states.

Goal and tasks

Development of a theoretical and methodological basis for the legal support of environmental protection in agriculture, taking into account the principle of sustainable development.

Identification of the main trends and promising areas of legal regulation of environmental protection in agriculture.

Study of the legal mechanisms of the European Union aimed at rational use of natural resources and environmental protection in agriculture.

Determination of the prospects for convergence of the legislation of the Republic of Belarus and the European Union (hereinafter - EU).

Main results

1. Agriculture is a separate branch of the economy in all states, being, among other things, one of the main sources of anthropogenic impact on the environment.

The main directions of activity in the field of environmental protection in agriculture in the EU and in the Republic of Kazakhstan are fixed in documents similar in their legal form - in the form of Programs. The fundamental documents in the EU include the programs that form the Common Agricultural Policy of the EU and the Sixth EU Action Program in the field of the environment. The Community Action Program in the field of the environment is defined as a political and legal document that defines the priority activities of the organization in the near future [1, P.44]. The main directions of environmental protection in order to achieve sustainable development are currently enshrined in the Sixth EU Environmental Action Program, approved by Decision of the European Parliament and of the Council No. 1600/2002 / EU of 22 July 2002. This document is intended to promote the integration of environmental interests into all policies pursued by the EU, the development of a global partnership for the environment and sustainable development. One of the strategic directions for achieving the established goals is the development of new EU legislation and the corresponding amendment of the current legislation [2, Art. 3]. In other words, we are talking about the need for greening all activities carried out within the EU in order to improve the environment, which implies taking into account environmental requirements in the production of products, stimulating the encouragement of actions by business entities aimed at protecting the environment. With regard to the rational use of natural resources and environmental protection in agriculture, it is proposed to use the ecosystem approach, which implies the promotion of sustainable rural development, multifunctional and sustainable agriculture, through the use of all the possibilities of the common agricultural policy and the promotion of more environmentally responsible management [2, Art. 6].

The united agricultural policy (hereinafter referred to as the UAP) is based on the agreement on the European Economic Community signed in 1957 and is a series of programs of a strategic nature in the field of agriculture. Along with the unified agrarian policy of the European Union, each state within the framework and taking into account this policy pursues its own agrarian policy. The need for environmental protection has been recognized as an important component of the UAP reform since 1997 in connection with the adoption of the Agenda 2000, the integration of the principle of sustainable development, which includes environmental protection as a mandatory component. The researchers note that the emergence of the main emphasis of the UAP, consisting in the complex correlation of financial support with environmental protection, food safety and quality standards, began in 2004 and now it can be argued that the EAP is a policy that increases responsibility for the preservation of the environment. compliance with the standards of production and processing of agricultural products, accelerating the development of rural areas [3]. One of the main instruments of the UAP is the payment of subsidies to farmers, taking into account the use of environmentally friendly production methods, which implies their compliance with environmental protection requirements. The aim of EU agricultural policy is to ensure a reliable supply of high quality products 
and support the environment, using renewable resources [4]. Among the tasks of the subsequent reform of the UAP, one of the main ones is the sustainable management and use of natural resources in the implementation of agricultural activities.

The Republic of Kazakhstan has also adopted a number of programs approved by the Decree of the President of the Republic of Kazakhstan, securing the basis for rational use of natural resources and environmental protection in agriculture, the main of which is the State Program for the Development of Rural Areas of the Republic of Kazakhstan for 2004-2010 [5]. The current programs in this area include the Concept of effective management of natural resources and the use of income from the raw materials sector of the Republic of Kazakhstan [6], the State program of the Government of the Republic of Kazakhstan for 2007-2009, approved by the Decree of the Government of the Republic of Kazakhstan on April 20, 2007 No. 319, which provides for the creation of a Unified State System for Monitoring the Environment and Natural Resources with the reform and modernization of the hydro meteorological service system [7], the State Program for the rational use of agricultural land for 2005-2008 [8]. It should be noted that the implementation of these programs took place in the past decade, the regulations that initiated their implementation have lost their force. Of the still operating, the State Program for the Development of the Agro-Industrial Complex of the Republic of Kazakhstan for 2017-2021 should be noted [9]. However, analysis of these documents testifies to the perception of the main trends in improving the legal regulation of environmental protection in the EU, while consolidating in the documents determining the further development of this industry, an integrated approach of the state to agriculture, which includes the development of agricultural production and sustainable development of rural areas.

Conclusion: The basis for the harmonization of the environmental policy of the EU and the Republic of Kazakhstan in the field of agricultural relations is the direction for the rational use and restoration of natural resources, primarily lands, enshrined in the legislation of both parties. The development of approaches to environmental protection and ensuring the ecological safety of agriculture in the Republic of Kazakhstan is carried out on the basis of principles similar to the basic principles of the Common Agricultural Policy pursued in the EU, which allows us to speak of the possibility of taking into account and positive perception of the EU experience in creating the economic interest of entities leading agricultural production, rational use of natural resources and environmental protection.
2. Protection of the environment and ensuring environmental safety in the course of economic activities are recognized as the directions of implementation of both domestic and foreign policy of the Republic of Kazakhstan [10]. Activities in this area are provided by the legislation of the Republic of Kazakhstan on environmental protection and rational use of natural resources (hereinafter referred to as environmental legislation). It is carried out both by state authorities and legal entities and citizens and is aimed at preserving the natural environment, rational use and reproduction of natural resources, as well as preventing harmful effects on the environment due to economic activities. In order to implement it, the Environmental Code of the Republic of Kazakhstan establishes the requirements for economic activity from the standpoint of ensuring environmental safety [11, Art.5]. So, in accordance with the Environmental Code of the Republic of Kazakhstan, subjects operating agricultural facilities are obliged to take measures to protect the components of the natural environment and natural objects, as well as to take measures to ensure compliance with environmental requirements. Two main directions of ensuring environmental safety in the implementation of agricultural activities follow from the norm of the law: a) the preservation of natural resources used in agricultural production, b) the implementation of general environmental measures, taking into account the specifics of agricultural activities, for example, the creation of sanitary protection zones around production facilities for agricultural use.

The implementation of the first direction is ensured by the requirements established in the natural resource legislation for the protection of individual components of the natural environment, imposed on legal entities and citizens engaged in agricultural production [11, section 8; 12]. This direction is traditional for environmental legislation, which has shown its effectiveness, but does not allow covering the entire range of possible measures to achieve environmental safety in the agricultural sector.

The implementation of the second direction (environmental measures taking into account the specifics of agricultural activities) should be based on the conceptual approach that has been formed in environmental and legal science regarding the interaction of environmental and legal and economic and legal norms, which is called "greening legislation" [13, p.95]. This approach makes it possible to require the establishment of complementary environmental requirements for a particular type of economic activity, simultaneously in the normative legal act of environmental and legal content (in the 
Environmental Code of the Republic of Kazakhstan) and in the legislative act regulating a certain direction of economic activity. However, in the legislation of the Republic of Kazakhstan there is no unified comprehensive normative legal act in the field of regulation of agrarian relations, the need for the development and adoption of which has been repeatedly pointed out in the legal literature [14, p.16].

It should be noted that the development of agrarian legislation in the CIS countries is also based on the adoption of a single regulatory legal act that enshrines the foundations of state policy in the agrarian sphere. A positive example is the standard draft legislative act of the EurAsEC of April 4, 2008 "On state support and development of the agro-industrial complex", where the principle of state regulation of the development of the agroindustrial complex is called its environmental safety [15]. The provisions of this document were adopted by the Russian Federation, where the Federal Law "On the Development of Agriculture" was adopted. This law includes the preservation and reproduction of natural resources used for the needs of agricultural production as the main goals of the state agrarian policy. In addition, it enshrines the possibility of providing state support to agricultural producers for carrying out certain measures by the state program in order to implement state policy aimed at ensuring ecological balance, protecting agricultural lands, and increasing their fertility [16, Articles 5, 13].

In Ukraine, the role of a comprehensive legislative act regulating the totality of agricultural and related relations is fulfilled by the Law "On State Support of Agriculture of Ukraine", which defines the foundations of state policy in budgetary, credit, price, insurance, regulatory and other spheres of state administration regarding the stimulation of agricultural production and the development of the agricultural market, as well as ensuring the food security of the population. Article 17 of the aforementioned Law provides for the allocation of budget subsidies for the implementation of targeted state programs aimed at increasing soil fertility, combating pests and diseases of agricultural plants and animals, farming in radiation-contaminated areas [17]. International obligations to ensure environmental protection in agriculture in Ukraine are based on the Agreement on Partnership and Cooperation between the European Communities and Ukraine, where the modernization and privatization of the agricultural sector of the economy should be carried out subject to ensuring environmental protection [18].

The Agreement on Enhanced Partnership and Cooperation between the European Union and its member states, on the one hand, and the
Republic of Kazakhstan, on the other hand, was ratified by the Law of the Republic of Kazakhstan dated March 25, 2016 No. 475-V and entered into force on March 1, 2020 [19]. Partnership and Cooperation Agreements (PCA) were concluded by the European Union with 11 former republics of the Soviet Union. The Agreement establishes an expanded partnership and cooperation between the Parties within the limits of their respective competences, based on a common interest and deepening of relations in all areas of its application. This cooperation is a process between the Parties that promotes international and regional peace and stability, economic development, and is based on principles that the Parties reaffirm with their international commitments, in particular within the UN and OSCE.

Findings:

2.1 Analysis of agricultural legislation and international agreements to which the Republic of Kazakhstan is a party demonstrates the need for a fundamentally new system of normative legal acts regulating agricultural relations, based on the separation of the main legislative act (Code).

Based on the obligations of the Republic of Kazakhstan arising from the content of interstate agreements, as well as based on the experience of neighboring states (Russia, Ukraine, the EU), the Republic of Kazakhstan requires the adoption of a law regulating the development of the agroindustrial complex and its state support.

2.2 Since environmentally sound agricultural development is one of the activities to ensure national security in general, one of the sections of the proposed law should be devoted to aspects of environmental protection and environmental safety in the implementation of agricultural activities.

In this section, in order to ensure environmental protection in agriculture, it is required to fix:

- environmental requirements for the operation of agricultural facilities;

- rules for the use of natural resources used in agricultural production;

- organizational and legal measures for environmental protection used in the implementation of agricultural production (indicating their specifics), such as, for example, departmental and industrial environmental control, etc .;

- the economic mechanism of nature management and environmental protection in agriculture, including measures to provide economic incentives for environmental protection, etc.

2.3 The adoption of a law regulating the development of the agro-industrial complex and its state support will make it possible to implement in practice an integrated approach to 
environmental protection in the implementation of agricultural activities, based on complementary environmental requirements established for entities engaged in agricultural production, at the same time in the environmental legal act content (in the Environmental Code of the Republic of Kazakhstan) and in a special legislative act.

2.4 The proposed approach also makes it possible to specify legal liability for violation of the requirements of environmental legislation in the implementation of agricultural activities on the basis of identifying the specifics of acts that violate environmental requirements in the implementation of agricultural activities (for example, the introduction of mineral fertilizers into the soil, the use of plant protection products, defoliants, etc. established standards), the establishment of measures of administrative and criminal liability in the relevant acts of legislation (Code of the Republic of Kazakhstan On Administrative Infractions, the Criminal Code of the Republic of Kazakhstan), as well as the specifics of compensation for harm caused to the environment.

3. In the present conditions, more attention from the legislator needs not so much further improvement of environmental legislation as the greening of the existing agricultural legislation and the development of general legal directions for environmental protection in agriculture, the introduction of environmental legal requirements into agricultural legislation and their consideration in the adoption of any economic decision. The main regulatory legal acts that determine the legal status of subjects of agricultural activity should contain separate norms establishing the rights and obligations for the use and protection of all natural objects involved in agricultural production, taking into account that environmental protection activities for agricultural organizations are not the main one and are associated with additional costs.

In the absence of a single legislative act in the Republic of Kazakhstan regulating the totality of agricultural relations, it is proposed that measures to protect the environment and ensure environmental safety be enshrined in laws aimed at legal support of certain areas of agricultural production:

On plant protection from July 3, 2002; [20];

About seeds from February 8, 2003 [21];

On veterinary activities of July 10, 2002 [22] and others.

The main provisions of the state policy in the field of environmental protection in agriculture, established in environmental legislation and which are the basis for constructive interaction of state authorities and international organizations, local governments and public associations to ensure a comprehensive solution to the problems of balanced development of agriculture and environmental protection, being enshrined in special acts regulating certain areas of agricultural activity, they can become the basis on which the corresponding environmental requirements will be further formulated in a single legislative act designed to regulate the entire set of agricultural relations. In other words, the requirements for rational use of natural resources and environmental protection in agriculture become an additional argument in favor of the development and adoption of a unified comprehensive legislative act in the field of regulation of agricultural relations.

4. The adoption of the State Program for the Development of the Agro-Industrial Complex of the Republic of Kazakhstan for 2017-2021 is based on the doctrine of sustainable development, which is undoubtedly a positive trend in the context of creating a legal basis for the further development of rural areas [9].

The legal foundations of sustainable development at the international level are enshrined in the Declaration of the UN Conference on Environment and Development (Rio de Janeiro, 1992), according to which environmental protection should be an integral part of the development process and cannot be considered in isolation from it [23, p. 721-723]. The Johannesburg Declaration on Sustainable Development, adopted at the World Summit on Sustainable Development (September 2-4, 2002), consolidates the collective responsibility of states to strengthen and streamline the interrelated and mutually supportive foundations of sustainable development - economic development, social development and environmental protection - on local, national, regional and global levels [24]. In legal science, sustainable development is defined as "environmentally sound economic and social development achieved by ensuring that environmental requirements are taken into account in the preparation, adoption and implementation of environmentally significant decisions in the interests of present and future generations" [25, p.16]. Thus, in accordance with the approach that has developed in international law and legal science, sustainable development presupposes a combination of three equal components - economic, social and environmental. Environmental activity in the Republic of Kazakhstan is also based on the principle of "scientifically grounded combination of environmental, economic and social interests of citizens, society and the state in order to ensure a favorable environment", which is reflected both in the CONCEPT of foreign policy of the Republic of Kazakhstan for 2020-2030 for the period up to 
2030 [10] and in the Environmental Code of the Republic of Kazakhstan [11].

It should be noted that in the considered State program for the development of the agroindustrial complex of the Republic of Kazakhstan for 2017-2021 the ecological aspect is not given due attention. In the Program, the main goals are declared: ensuring the sustainability of the socio-economic development of the village and improving its demographic situation on the basis of increasing the economic efficiency of the agroindustrial complex, increasing the income of the rural population, the level of social, household and engineering infrastructure of rural settlements, preserving and improving the environment in them, attracting and rational use of investments. Among the main tasks, there is not a single one directly related to environmental protection. The leading directions of the Program implementation are also not directly related to environmental protection. Nevertheless, the analysis of the provisions of the Program allows us to speak about its focus on the rational use of natural resources (as one of the traditional aspects of environmental protection) with a specific indication of the need to take into account international experience in this area. The Program reveals the main provisions for transforming the system of state support for the agro-industrial complex, taking into account international practice. A set of measures is envisaged in order to preserve and rational use of land and water resources, achieve and maintain optimal agrochemical properties of soils of agricultural lands, implement measures to combat soil degradation and chemical pollution, including the development (following the model of the European Union) regulations for the use of agricultural land ensuring the preservation of soil fertility, prevention of water and wind erosion, washout of mineral fertilizers into water bodies and groundwater; development and implementation in agricultural production of waste-free and lowwaste technologies and some others.

Conclusion: Kazakh legislation in the economic, social and environmental areas is generally based on the principle of sustainable development. With the further development of agrarian legislation, including legal support for environmental protection in the implementation of agricultural production, it will be necessary to consistently consolidate the named principle as one of the principles of legislation regulating agricultural and related activities. The principle of a scientifically grounded combination of environmental, economic and social interests as three equivalent components should be legalized in a comprehensive legislative act designed to regulate the entire totality of agricultural relations.

\section{Bibliography:}

1. Kalinichenko P.A. Environmental protection in the activities of the European Community (international legal aspect). Diss. ... Cand. jurid. sciences. M., 2001.

2. Sixth Community Action Program in the field of the environment: Decision of the European Parliament and the Council of 22 July 2002 No. 1600/2002 / EC // http://eulaw.edu.ru/documents/ legislation/okr_sreda/6progr.htm\#_ednref1

3. Sustainable development of the region // Vadybos mokslas ir studijos - kaimo verslų ir jų infrastruktūros plètrai = Management theory and studies for rural business and infrastructure development / Zhytomyr National Agroecological University, Lithuanian University of Agriculture, Klaipeda University, 2010, nr. 21 (2), p. 43-52, ISSN 1822-6760 (EBSCO, Business Source Complete, Central \& Eastern European Academic Source).// https://www.laei.lt/?mt=mokslo-p ublikacijos\&straipsnis=101\&metai=2010

4. Iveta Kelpe. Fair agricultural policy // http://rus.morning.Iv/opinion/iveta-kelpe-spravedlivayaselskohozyajstvennaya-politika.d?id=39298603

5. The Republic of Kazakhstan President's Decree of 10 July 2003 N 11490 State Program of Rural Development of the Republic of Kazakhstan for 2004-2010 // http://adilet.zan.kz/rus/docs/ U030001149_/links

6. Resolution of the Government of the Republic of Kazakhstan dated September 25, 2013 No. 1003 On the concept of effective management of natural resources and the use of income from the raw materials sector of the Republic of Kazakhstan. // http://adilet.zan.kz/rus/docs/ P1300001003

7. State program of the Government of the Republic of Kazakhstan for 2007-2009, approved by the Decree of the Government of the Republic of Kazakhstan on April 20, 2007 No. 319 // http:// adilet.zan.kz/rus/docs/P070000319_/links

8. Program for the rational use of agricultural land for 2005-2008. Decree of the Government of the Republic of Kazakhstan dated January 5, 2005 No. 3. Abolished by the decree of the Government of the Republic of Kazakhstan dated September 19, 2009 No. 1411// http://adilet.zan.kz/ rus/docs/P050000003_ 
9. State program for the development of the agro-industrial complex of the Republic of Kazakhstan for 2017-2021. Resolution of the Government of the Republic of Kazakhstan dated July 12, 2018 No. 423. // http://adilet.zan.kz/rus/docs/P1800000423

10. CONCEPT of foreign policy of the Republic of Kazakhstan for 2020-2030. Approved by the Decree of the President of the Republic of Kazakhstan dated March 6, 2020 No. 280 // https:// www.akorda.kz/ru/legal_acts/decrees/o-koncepcii-vneshnei-politiki-respubliki-kazahstan-na2020-2030-gody

11. ENVIRONMENTAL CODE OF THE REPUBLIC OF KAZAKHSTAN. Code of the Republic of Kazakhstan dated January 2, 2021 No. 400-VI 3PK // http://adilet.zan.kz/rus/docs/K2100000400

12. Land Code of the Republic of Kazakhstan. Code of the Republic of Kazakhstan dated 20 June, 2003 No.442. // http://adilet.zan.kz/eng/docs/K030000442_

13. Petrov, V.V. Environmental law of Russia: textbook. for universities / V.V. Petrov. M.: BEK, 1995.

14. Erkinbayeva, L.K. Agrarian legal relations in the Republic of Kazakhstan: Author's abstract. diss. ... for a job. doct. jurid. Sciences of the Republic of Kazakhstan. Almaty, 2008.

15. On state support and development of the agro-industrial complex: Resolution of interparliamentary EurAsEC Assembly, 4 Apr. 2008, No. 9-11 // Documents of the IPA EurAsEC [Electronic resource]. - 2011.

16. The Russian Federation. Federal Law "On the Development of Agriculture" dated December 29, 2006 N 264-FZ (last edition). // http://www.consultant.ru/document/cons_doc_LAW_64930/

17. On State Support of Agriculture of Ukraine. The Law of Ukraine dated June 24,2004 No. 1877-IV (with amendments and additions as of 05.11.2020) //https://online.zakon.kz/document/?doc_ id $=30457306$

18. 1994 EU-Ukraine Partnership and Cooperation Agreement // eulaw.edu.ru/spisok-dokumentov-po-pravu-evropejskogo-soyuza/soglashenie-o-partnerstve-i-sotrudnichestve-mezhdu-es-iukrainoj- 1994-g /

19. Enhanced Partnership and Cooperation Agreement between the European Union and its Member States, on the one hand, and the Republic of Kazakhstan, on the other hand (Astana, December 21, 2015) // https://online.zakon.kz/document/?doc_id = 37496546 \# pos = 2; -106

20. On protection of plants. The Law of the Republic of Kazakhstan dated 3 July, 2002 No. 331.// http://adilet.zan.kz/eng/docs/Z020000331

21. On seed production. The Law of the Republic of Kazakhstan dated February 8, 2003 No. 385-II "'" // https://online.zakon.kz/document/?doc_id=1036961

22. On Veterinary Medicine. The Law of the Republic of Kazakhstan dated 10 July, 2002 No. 339. // http://adilet.zan.kz/eng/docs/Z020000339

23. Declaration on Environment and Development: Declaration of the United Nations Organization, June 14, 1992, Rio de Janeiro // International law in force: in 3 volumes / comp. Yu.M. Kolosov, E.S. Krivchikova. - M.: Publishing house of Moscow. Independent. in-that international. Law, 1997. -- T. 3.

24. Johannesburg Declaration on Sustainable Development of September 4, 2002 // [Electron. resource] / United Nations, 2009. Mode of access: http: // www. un.org. // Russian

25. Vershilo, N.D. Ecological and legal foundations of sustainable development: author. diss. ... Dr. Law. Sciences / Institute of State and Law. - M., 2008. 